Kumawula, Vol. 3, No.2, Agustus 2020, Hal 239 - 245 DOI: https://doi.org/10.24198/kumawula.v3i2.27038

ISSN 2620-844X (online)

Tersedia online di http://jurnal.unpad.ac.id/kumawula/index

\title{
PENGENALAN TEKNIS ANALISIS INPUT-OUTPUT UNTUK PERENCANAAN PEMBANGUNAN DAERAH DI KABUPATEN TEMANGGUNG
}

\author{
Firmansyah $^{1}$, FX. Sugiyanto ${ }^{2}$, Evi Yulia Purwanti ${ }^{3}$, Maruto Umar Basuki ${ }^{4}$, Marwini ${ }^{5}$, \\ Akhmad Syakir Kurnia ${ }^{6}$, Shanty Oktavilia ${ }^{{ }^{*}}$ \\ ${ }^{1}$ Fakultas Ekonomika dan Bisnis, Universitas Diponegoro \\ 2,3,4,5,6,7 Fakultas Ekonomi, Universitas Negeri Semaramg \\ *oktavilia@mail.unnes.ac.id
}

\begin{abstract}
ABSTRAK
Salah satu pendekatan analisis yang secara luas telah diimplementasikan dalam perencanaan pembangunan daerah adalah analisis input-output (I-O). Analisis I-O mampu memberikan dasar bagi perencanaan pembangunan berbasis sektoral sekaligus memberikan simulasi skenario kebijakan yang masuk akal untuk diimplementasikan. Tabel I-O Kabupaten Temanggung Tahun 2016, disusun oleh Bappeda Kabupaten Temanggung Bersama dengan Badan Pusat Statistik Jawa Tengah pada tahun 2018. Kegiatan Pengabdian kepada Masyarakat (PKM) ini betujuan memberikan pelatihan dan pendampingan teknis menggunakan analisis I-O untuk perencanaan pembangunan daerah. Penguasaan Analisis I-O diharapkan dapat menjadi material dalam menyusun kebijakan pembangunan untuk jangka waktu 5 (lima) tahun yang akan datang. Hasil pengabdian menunjukkan peserta pengabdian secara teknis mengerti dan mampu menganalisis dengan Tabel IO simulatif. Pendampingan dilakukan setelah peserta menggunakan dan menganalisis dengan Tabel I-O Kabupaten Temanggung, sebagai salah satu sumber informasi dalam penyusunan perencanaan kebijakan dan program strategis pembangunan.
\end{abstract}

Keywords: Tabel I-O, analisis I-O, pelatihan, pendampingan, perencanaan daerah.

\begin{abstract}
One of the analytical approaches that has been widely implemented in regional development planning is input-output (I-O) analysis. I-O analysis, based on an I-O table, can provide the basis for sectoral development planning by simulating the impact of policy scenarios. One area that has published Table I-O is Temanggung Regency, to represent its 2016 economy. Community Service Activities (PKM) aims to provide training and technical assistance to Temanggung Regency planners in using I-O analysis to design regional development planning documents. The results of this activity show that the participants technically understood and were able to analyze with Input-Output. Assistance was also carried out after the participants were able to use and analyze the Temanggung Regency I-O Table, and subsequently could become one source of information in the preparation of strategic development policies and programs.
\end{abstract}

Keywords: Table I-O, I-O analysis, training, technical guidance, regional planning

\section{PENDAHULUAN}


Keselarasan proses pembangunan daerah tidak lepas dari tiga aspek penting (Todaro dan Smith, 2015). Pertama adalah pertumbuhan ekonomi, karena proses pembangunan harus terjadi peningkatan standar hidup dari pertumbuhan ekonomi. Kedua, Peningkatan Jati diri (self esteem), yaitu pembangunan dan pertumbuhan ekonomi dinilai mampu memperbaiki kondisi sosial, politik dan ekonomi dan sosial masyarakat. Ketiga adalah kebebasan (freedom) yang berarti bahwa proses pembangunan diharapkan mampu meningkatkan kebebasan berpikir, dan semakin banyak pilihan masyarakat yang ditandai dengan peningkatan konsumsi barang dan jasa. Ketiga hal tersebut, mengisyaratkan bahwa pembangunan ekonomi di daerah juga harus dimulai dari, untuk dan oleh pemda, masyarakat danseluruh pelaku ekonomi di daerah (endogenous development). Perencanaan pembangunan daerah yang berbasis data yang tepat, terarah dan terukur sangat penting untuk dibangun dalam rangka memandu pencapaian tujuan pembangunan daerah.

Para pendukung perencanaan ekonomi di negara berkembang berpendapat bahwa ekonomi pasar yang tidak terkendali seringkali menyebabkan dualisme ekonomi, yaitu pasar yang tidak stabil, investasi rendah di sektor-sektor utama, dan tingkat penyerapan tenaga kerja rendah. Perencanaan menjadi hal yang penting selalu dilakukan sebagai sarana penting untuk mendampingi dan mempercepat pertumbuhan ekonomi di hampir semua negara berkembang (Todaro dan Smith, 2015)

Dalam praktik di lapangan, dinamika sosial ekonomi di daerah sangat dipengaruhi oleh faktor internal dan eksternal (Kolawole dan Ojapinwa, 2013). Penyusunan dokumen perencanaan seringkali kurang dan bahkan tidak didukung oleh ketersediaan data yang akurat dari sumber yang terpercaya. Penyusunan dokumen perencanaan juga kurang didukung dengan penggunaan alat analisis yang dapat dipertanggungjawabkan. Perencana di daerah seringkali hanya mengunakan metode trend dari data historis yang juga terbatas. Penggunaan data yang akurat dan alat analisis yang memadai, sebenarnya merupakan salah satu upaya pencegahan terhadap penetapan program dan kegiatan pembangunan yang tidak efektif dilakukan, sehingga ketidaktercapaian tujuan pembangunan dapat diminimalkan. Oleh karena itu, dalam rangka penyusunan dokumen perencanaan pembangunan daerah, diperlukan sumber daya manusia di daerah yang kompeten dalam analisis ekonomi yang mendukung penyusunan perencanaan daerah.

Perencanaan pembangunan daerah membutuhkan metode yang tepat dalam menyusun proyeksi capaian pertumbuhan sektoral di masa yang akan datang. Dalam rangka merespon 
kondisi tersebut, salah satu pendekatan yang secara luas telah diimplementasikan dalam perencanaan pembangunan daerah adalah dengan menggunakan pendekatan analisis inputoutput (I-O). Analisis I-O merupakan salah satu metode yang dapat digunakan untuk Menyusun proyeksi target capaian pembangunan suatu daerah melalui analisis dampak yang ditimbulkan pada masing-masing sektor ekonomi yang tercantum dalam tabel. Analisis I-O mampu memberikan dasar bagi perencanaan pembangunan berbasis sektoral sekaligus memberikan simulasi skenario kebijakan yang masuk akal untuk diimplementasikan. Kegiatan Pengabdian kepada Masyarakat (PKM) ini dilakukan dengan tujuan memberikan pelatihan dan pendampingan teknis analisis I-O untuk perencanaan pembangunan daerah. Penguasaan Analisis I-O diharapkan dapat menjadi material dalam menyusun kebijakan pembangunan untuk jangka waktu 5 (lima) tahun yang akan datang, terutama sebagai salah satu sumber informasi dalam penyusunan perencanaan kebijakan dan program strategis pembangunan. Kegiatan Pengabdian kepada masyarakat di Kabupaten Temanggung karena pada tahun 2017 memiliki Tabel I-O baru dengan tahun Tabel 2016. Pengabdian ini diperlukan sebagai kegiatan pengenalan secara teknis dan pendampingan penggunaan Tabel IO terutama bagi bagi staf perencana di daerah. Secara khusus kegiatan pengabdian kepada masyarakat ini memiliki tiga tujuan, yaitu re-calling pemahaman data indikator ekonomi, dan beberapa analisis ekonomi untuk perencanaan pembangunan daerah. Mengenalkan Tabel Input- Output dan nilai pentingnya bagi perencanaan pembangunan daerah. Melakukan pendampingan menggunakan Tabe Input Output untuk perencanaan pembangunan daerah.

\section{METODE}

Pengabdian kepada Masyarakat ini diawali dari kegiatan persiapan, yaitu proses perijinan untuk berkolaborasi dengan Bappeda Kapaten Temanggung sebagai mitra PKM. Tim Pengabdi menyediakan instruktur dan fasilitator Pelatihan dan Pendampingan. Sedangkan Mitra, Bappeda Kabupaten Bappeda Kabupaten Temanggung mengkoordinasikan peserta pengabdian yang berkomitmen menyelesaian seluruh rangkaian pelatihan yang dijadwalkan. Sasaran kegiatan pengabdian adalah staf perencana di Bappeda Kabupaten Temanggung dan staff perencana pada instansi teknis (dinas dan kantor). Secara khusus kegiatan ini dilaksanakan untuk memberikan bimbingan teknis analisis I-O pada SDM fungsional Perencana di Kabupaten Temanggung. Kegiatan pelatihan diawali dengan identifikasi kemampuan peserta PKM dalam hal pemahaman Tabel I-O dan analisis menggunakan Tabel 
I-O. Identifikasi ini dilakukan dengan mengemukakan pertanyaan tentang beberapa istilah penting dalam analisis I-O untuk direspon secara interaktif oleh peserta.

Kegiatan dilaksanakan dengan metode ceramah dan diskusi dua arah untuk dan praktik analisis dengan menggunakan Tabel I-O. Fasilitator adalah Tim Pengabdian yang memiliki kompetensi yang cukup di bidang perencanaan pembangunan dan memiliki penguasaan analisis untuk perencanaan dengan cukup baik.

\section{Gambar 1. Kegiatan Pelatihan dan Pendampingan di Kabupaten Temanggung}

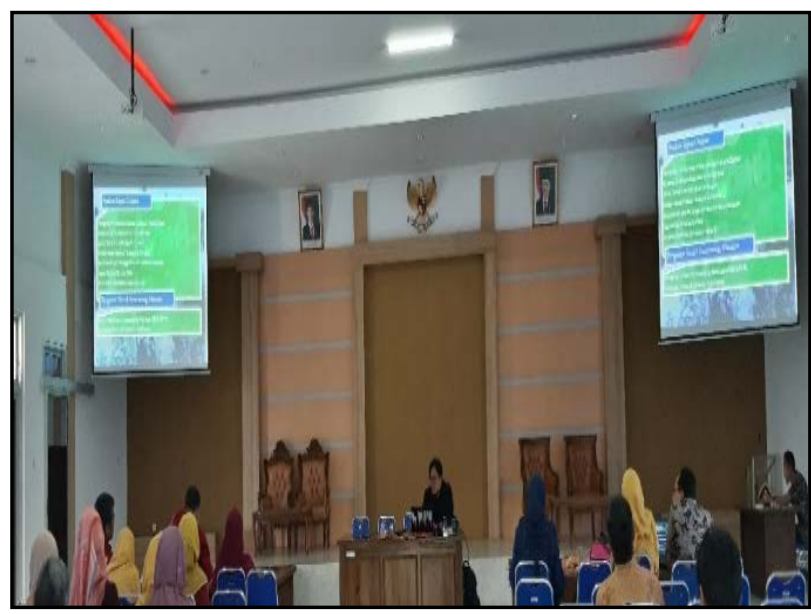

(a) Kegiatan Pelatihan

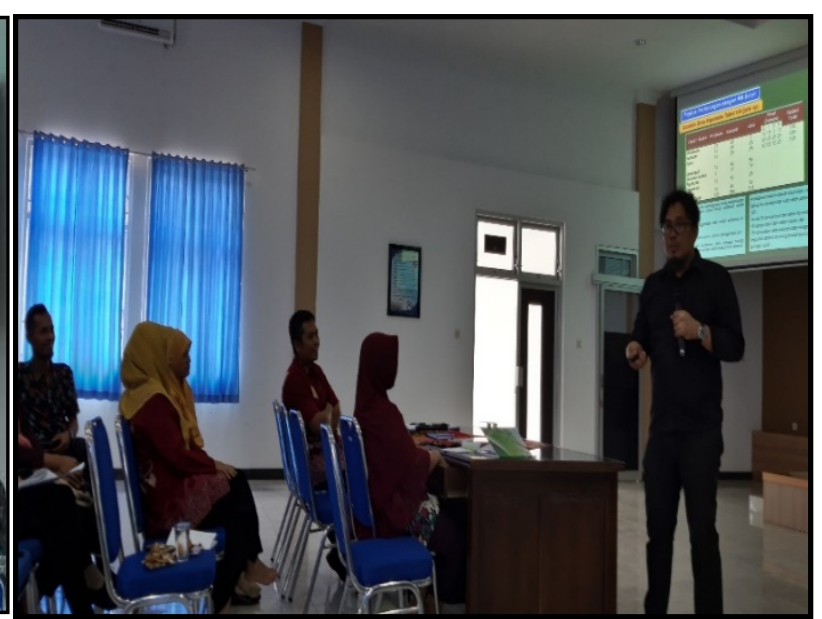

(b) Kegiatan Pendampingan

Pada akhir kegiatan PKM, dilakukan penilaian tingkat keberhasilan sekaligus evaluasi pelaksanaan PKM. Penilaian indeks keberhasilan PKM perencanaan pembangunan dengan metode input output di Kabupaten Temanggung dilakukan melalui panduan kuesioner sederhana. Aspek-aspek yang dinilai sebagai evaluasi adalah penguasaan teknis, kedalaman materi dan pemahaman terhadap materi Perencanaan Pembangunan dengan Metode Input Output.

\section{HASIL DAN PEMBAHASAN}

Amanat Undang-undang nomor 25 Tahun 2004 tentang Sistem Perencanaan Pembangunan Nasional pasal 5 menyebutkan bahwa: Sistem Pembangunan Nasional adalah satu kesatuan tata cara perencanaan pembangunan untuk menghasilkan rencana-rencana pembangunan dalam jangka panjang, jangka menengah, dan tahunan yang dilaksanakan oleh unsur penyelenggara negara dan masyarakat di tingkat pusat dan daerah. Perincian tahapan pembangunan meliputi: 1) penyusunan rencana; 2) penetapan rencana; 3) pengendalian pelaksanaan rencana; dan 4) evaluasi pelaksanaan rencana. Keempat tahapan diselenggarakan 
secara berkelanjutan sehingga secara keseluruhan membentuk satu siklus perencanaan yang utuh.

Penyusunan dokumen perencanaan dan analisis ekonomi seringkali tidak mampu dilakukan oleh aparat perencana di daerah secara mandiri. Hal ini dikarenakan ketidakmampuan dalam menyusun dokumen perencanaan dan mereviu. Hal ini yang menyebabkan seringkali terjadi kegagalan dalam pencapaian realisasi target. Kemampuan analisis staf fungsional Pemda yang terbatas menyebabkan dokumen perencanaan disusun dengan alat analisis yang terbatas pula.

Tabel I-O dan analisisnya pertama kali dikembangkan oleh Professor Wassily Leontief sekitar akhir tahun 1930 (Miller dan Blair, 1985). Tabel ini kemudian dikembangkan oleh para pemodel I-O yang diterapkan sebagai alat analisis dan perencanaan yang praktis dan bersifat kuantitatif (BPS, 2008). Analisis dengan Model I-O untuk perencanaan ekonomi, dikembangkan bada banyak kajian antara lain analisis ekonomi dari sektor pariwisata, APBN dan ekspor, serta dampak pertumbuhan ekonomi terhadap penggunaan sumber daya alam, teknologi dan lingkungan banyak dilakukan dengan menggunakan model I-O.

Tabel I-O merupakan tabel yang sangat khas menyajikan informasi transaksi barang dan jasa yang terjadi antar sektor ekonomi dengan bentuk penyajian berupa matrik. Kekhasan dari Tabel I-O adalah pada matriks yang menunjukkan menunjukkan inter-dependensi berbagai sektor dalam perekonomian secara komprehensif (Firmansyah, 2006).

Keterbatasan dari Tabel I-O terutama bagi daerah adalah proses penyediaan data tabel yang cukup lama dan relatif mahal. Oleh karena itu, pemerintah daerah beserta Badan Pusat Statistik, biasanya tidak akan menyediakan Tabel I-O dalam series tahunan. Keterbatasan effort yang besar dalam membangun tabel input-output seringkali menjadi titik argument untuk menyediakan Tabel I-O. Sisi kepraktisan pembuatan Tabel I-O dan ketidakpahaman penggunaan Tabel I-O untuk analisis masih merupakan subjek alasan bagi pemerintah daerah untuk menyediakan tabel ini. Kabupaten Temanggung bersama dengan BPS pada tahun 2017 mulai menyusun Tabel I-O Kabupaten Temanggung Tahun 2016. Meskipun demikian kemampuan aparatur dalam memahami dan menganalisis menggunakan tabel ini untuk penyusun perencanaan masih sangat terbatas.

Solusi yang ditawarkan oleh Tim Pengabdian kepada Masyarakat ini adalah Aparatur perencana daerah, yang terdiri dari fungsional perencana di Bappeda Kabupaten Temanggung. Selain itu juga seumber daya manusia yang berada pada perencana dan bidang riset dan pengembangan yang sering menggunakan analisis ekonomi di beberapa Organisasi 
Perangkat Daerah (OPD) di Kabupaten Temanggung. Aparatur dari OPD yang terlibat sebagai peserta dalam pengabdian kepada masyarakat ini antara lain dinas penanaman modal, dinas perdagangan dan perindustrian, dinas pariwisata, dinas pertanian, Sekda bagian perekonomian, dan dinas terkait yang berkontribusi dalam penyusunan dokumen perencanaan daerah. Pengenalan Tabel I-O dan sistematika cara bekerjanya table dijelaskan dengan sangat runtut kepada peserta pengabdian. Metode melalui ceramah disertai dengan praktik yang terstruktur dalam beberapa sesi pelatihan. Sesi pelatihan diawali dengan Recharging Perencanaan pembangunan dan hubungannya dengan penggunaan analisis I-O. Sesi selanjutnya adalah sesi teknis pengenalan Tabel I-O dan aplikasi Tabel I-O untuk analisis perencanaan pembangunan daerah Kabupaten Temanggung

Respon dan antuisme peserta pelatihan sangat baik. Hal ini ditunjukkan dengan interaksi tanya jawab dan diskusi yang berkembang dalam sesi pelatihan dan pendampingan. Kegiatan pendampingan selain dilaksanakan dalam tiga kali kunjungan, juga dilaksanakan secara daring. Respon positif dari kegiatan ini juga diketahui dari hasil evaluasi sederhana yang diberikan oleh peserta. Pertanyaan untuk evaluasi merupakan pertanyaan tertutup yang berisi informasi tentang dua hal yaitu (1) apakah pelatihan ini bermanfaat dan (2) apakah pelatihan semacam ini perlu dilaksanakan di masa yang akan datang.

Hasil perhitungan penilaian evaluasi dilakukan dengan menghitung rasio antara jumlah penilaian peserta pelatihan dibandingkan dengan jumlah skor tertinggi yang diharapkan. Skor penilaian peserta berkisar antara nilai 1 sampai dengan 5. Pencapaian evaluasi dari hasil respon peserta sebesar sebesar 94,11\% yang berarti tingkat keberhasilan pelaksanaan Pengabdian kepada Masyarakat di Kabupaten Temanggung adalah baik sekali. Selain itu PKM ini juga dinilai berhasil dilihat dari antusiasme peserta pelatihan yang hadir. Pada awalnya target peserta adalah 20 orang dan realisasi di lapangan jumlah peserta PKM di Kabupaten Temanggung mencapai 34 orang. Sehingga penilaian kehadiran peserta yang ditunjukkan dengan rasio realisasi dan target peserta adalah $170 \%$ dinilai berhasil, karena melampaui target peserta yang diharapkan.

\section{SIMPULAN}

Pelaksanaan PKM berlansung sesuai dengan skedul dengan respon positif dari peserta sasaran terutama staff fungsional perencana di Kabupaten Temanggung. Hasil evaluasi pelaksanaan menunjukkan tujuan PKM berhasil sesuai yang diharapkan. Pelatihan dan penyegaran tentang indikator pembangunan dan alat analisis perlu dilakukan secara kontinyu bagi staf perencana 
di daerah. Hal ini dikarenakan aparatur perencana di daerah seringkali mengalami perpindahan bagian dan mutasi jabatan. Kegiatan pelatihan dan pendampingan dapat dilaksanakan melalui kerjasama dengan institusi perguruan tinggi melalui kegiatan Pengabdian kepada Masyarakat.

\section{UCAPAN TERIMAKASIH}

Tim Pengabdian kepada Masyarakat mengucapkan terimakasih kepada Ketua Bappeda Kabupaten Temanggung beserta jajarannya.

\section{DAFTAR PUSTAKA}

Badan Pusat Statistik. 2008. Kerangka Teori dan Analisis Tabel Input-Output, Jakarta: Badan Pusat Statistik

Firmansyah. 2006. Operasi Matrix dan Analisis Input-Output (IO) untuk Ekonomi - Aplikasi Praktis dengan Microsoft Excel dan MATLAB. Semarang: BP Undip dan LSKE FEUNDIP.

Kolawole, B.O dan Ojapinwa, T.V. 2013. Economic Planning Models for Development: The Relevance for a Developing Economy. International Journal of Humanities and Social Science Vol. 3 No. 16 Special Issue - August 2013.

Miller, R. dan Blair, P. 1985. Input-Output Analysis: Foundations and Extentions. New Jersey: Prentice-Hall, Inc.

Todaro, M.P dan Smith, S.C. 2015. Economic Development Twelfth Edition, Boston, Pearson.

. 2004. Undang-undang nomor 25 Tahun 2004 tentang Sistem Perencanaan Pembangunan Nasional 